Оливера РАШИКं-ЦАНЕВСКА

\title{
ПРВИ РЕАКЦИИ НА РОДИТЕЛИТЕ НА ДЕЦА СО ПРЕЧКИ ВО РАЗВОЈОТ
}

\author{
„Сийе среќни семејсиива си ирилетаай еяно на оруїо, \\ а секое несреќно семејсйво е несреќно на свој начин “ \\ Лав Толстој (во Ана Каренина)
}

\section{Кратка сооржина}

Коїа рояийелийе йрвйай кंе яознаай оека нивнойо gейе има некои йречки во развојой, нивнииее живойи моменйално се менуваай и ииие мораай gа се соочай со мноїу йреоизвии. Прео сѐ, йие ке мораай gа іи йроменай очекувањайа ийо іи имале йостиавено за своейо gетие, ке мораай qа се сиравай со

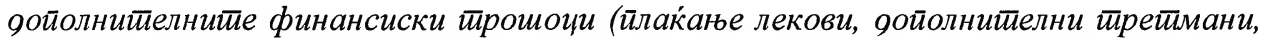
иривайни часови, ирревоз), како и со мноіубројнитие ойсустива оя рабойа или и яа се ойкажай оо неа, биоејки некој мора яа се ірижи за яейейо со йречки во развојой. Некои оя нив можеби ќе се соочай и со сочијална изолачија оя ситрана на йоширокойо семејситво, сосеяийе и иријаителитие.

Реакциийе на рояителитее, во моменйой на йосйавување на яијаінозайа кај нивнойо gейе, се исклучиво иноивиоуални, йа нивнойо йознавање е оя іолемо значење за йрочесой на рехабилитиачија, биоејќ йој мноїу ќе зависи оо сйавой на

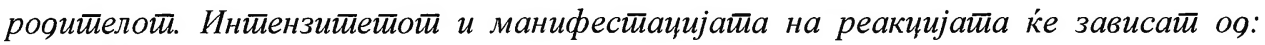

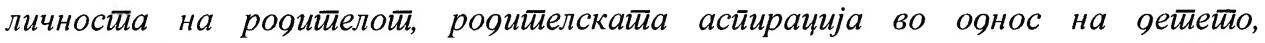

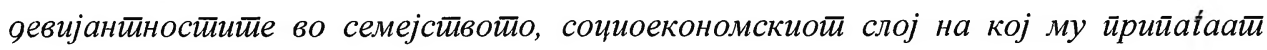
рояийелийе и сл.

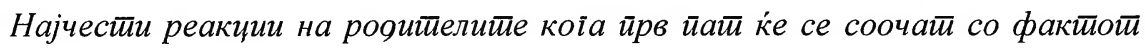
яека имаай оейе со йречки во развојой се: иок, неіирање, луииина, ситрав, срам, вина, збунетиосй, немоќносй, разочарување, оіорченосй, зависй и йаїа.

Клучни зборови: СЕМЕЈСТВА, РОДИТЕЛИ, ДЕЦА СО ПРЕЧКИ ВО РАЗВОЈ, РЕАКЦИИ

Иако ни се чини дека знаеме сѐ за семејството, неговото научно проучување не е ниту малку едноставно, така што во оваа област постојат низа нерасчистени прашања и проблеми - почнувајќи од историскиот развој на семејството, преку неговата структура и функција, односите спрема општеството, внатрешните односи и динамиката. Сложеноста на семејството како посебна општествена група и тешкотиите што се појавуваат при неговото 
проучување бараат мултидисциплинарна соработка, па оттаму семејството е предмет на проучување на повеќе науки. Врз основа на тоа постојат и многубројни дефиниции за семејството.

Како поим во секојдневниот говор со семејство означуваме заедница од родители и потомци. Тоа претставува примарна општествена група која се базира врз био-социјални и емоционални односи. Емоционалните односи се интензивни, интеракцијата е долготрајна и разновидна, а меѓусебната зависност и влијанијата се големи (Rot, 2006).

Поимот семејство не е повеќе синоним за традиционалното нуклеарно семејство. Една од дефинициите која ги зема предвид многубројните семејни варијации е: „Семејство е која било група лица поврзани со брак, сродство (крвно сродство), посвојување или која било сексуална врска во која луѓето се поврзани едни со други во интимен однос, членовите го гледаат својот идентитет како значително поврзан со групата која поседува сопствен идентитет“" (Seibt, 1996).

Денес се среќаваме со сѐ повеќе нетрадиционални семејства, како што се: семејства со еден родител (самохрани мајки, разведени родители), реконструирани семејства (повторно засновани бракови и семејства - step families), семејства со истородни родители (геј и лезбиски семејства со деца од претходни бракови, деца посвоени или добиени на некој друг начин), згрижувачки и посвојувачки семејства (Seibt,1996). Секое од овие семејства има специфични потреби и се сретнува со специфични предизвици на кои не можат секогаш да одговорат сами.

Семејството е незаменлива средина во која детето се формира како личност, живее во него, задоволувајќи ги некои од своите најважни потреби што можат да се задоволат само во семејството. Како прв и најзначаен агенс на социјализација, семејството е и најодговорно за обезбедување оптимални услови за развој на детето.

Раѓањето на детето во семејството најчесто е извор на радост и формирање на нови чувства, а во бракот кој дотогаш бил без деца доаѓ до вистинско формирање на семејството и развивање на основното семејно чувство кое се карактеризира со нежен, грижлив и заштитнички став. Родителството може да донесе чувство на неизмерна среќа, гордост, самоостварување, потврда на идентитетот и интегритетот, успех (С̌udina - Obradović \& Obradović, 2006), но, исто така, може да доведе до појава на замор, напор, стрес, а понекогаш и губење на можноста за самореализација во други области (С̌udina - Obradović \& Obradović, 2006; Ali, 2008). Меѓутоа, раѓањето на детето со пречки во развојот претставува силен предизвик и закана за нарушување на семејниот живот. Нашите и светските искуства и истражувања укажуваат на тоа дека раѓањето на детето со пречки во развојот неоспорно предизвикува стресна промена во семејството и најчесто го менува неговото секојдневно функционирање и ја одредува насоката на неговиот понатамошен развој. Барањата што се поставуваат пред семејството, односно пред сите негови членови, не се мали и можат да го загрозат секој од нив поединечно, но и семејството во целост. Според Seligman и Darling (2007), раѓањето на детето со пречки во развојот ги става родителите и целото семејство пред големи предизвици и искушенија, па поради тоа тие ова родителство го нарекуваат „неизвесно патување“. 
Сето она што важи за семејството и улогата на родителите во развојот на детето што не е попречено во развојот важи и за родителите што имаат дете со пречки, со тоа што родителите на ова дете имаат и специфични проблеми кои другите родители ги немаат или ги немаат во толкав обем, тежина и разновидност (Чичевска-Јованова и ДимитроваРадојичиќ, 2013). Многу истражувања предупредуваат на неповолното влијание од појавата на „хендикепиран“ член во семејството врз животот на целото семејство. Во некои од нив се истакнува тврдењето дека „хендикепираното“ дете значи и „хендикепирано“ семејство (Stamenkova-Trajkova и Trajkov, 1997).

Што е тоа што се случува и што може да го наруши функционирањето на семејството, но и родителството во овој случај? За развојот и растењето на детето, посебно во првите години од животот, од особена важност е хармоничното функционирање на брачните партнери, односно на родителите на детето како семеен потсистем.

Детето со тешкотии во развојот го зголемува физичкото, психичкото и временското оптоварување во семејството.

Истражувањата со родители на деца со попреченост посочуваат неколку важни ризик-фактори со кои се соочуваат родителите. Родителите на деца со попреченост имаат поголема веројатност да доживеат поголеми животни промени, вклучувајќ разводи, операции и чести преселби. Тие, исто така, многу почесто искусуваат нервози во текот на денот отколку останатите родители. Ваквите нервози често стануваат извор на кумулативен стрес, кој во комбинација со различни животни збиднувања води до проблеми за самите родители, но и за децата.

Во семејствата со дете со типичен развој, растот и развојот се одвива спонтано. Додека се мали, тие зависат од помошта на своите родители, но, како што растат, ангажманот на нивните родители се намалува. На детето со типичен развој не му се потребни ниту многу поттикнувања ниту време за да се научи самостојно да ги извршува секојдневните активности.Но, тоа не е случај со децата со пречки во развојот. И покрај достигнувањето на одредена возраст кога тие треба да се осамостојат, овие деца и понатаму се зависни од своите семејства, особено од мајката. Продолжената зависност на децата може да придонесе кон научена беспомошност, која понатаму има други негативни влијанија (Utley, Hoehn, Soraci \& Baumester, 1993).

Многу студии се занимавале со истражување на тешкотиите на кои наидуваат родителите при одгледување на децата со пречки во развојот (Boyce et all., 2003; Snowdon \& et all., 1994; Ayers, 2010).

Во своето истражување Crowe (1993) го споредувала времето кое им е потребно на мајките за негување на своите деца помлади од 5 години. Резултатите од ова истражување покажале дека мајките со деца со повеќкратна попреченост поминуваат 39,7 часа неделно во негувањето на своето дете, на мајките со деца со Даунов синдром им се потребни 32,8 часа, додека мајките на деца со типичен развој трошат околу 33 часа неделно.

Ангажираноста во активностите од секојдневниот живот на детето е временски со големи барања, а се зголемува во зависност од тешкотиите на детето. Покрај ова, како што детето со тешкотии во развојот расте и добива на тежина, така и секојдневните задачи на 
лицето што се грижи за него во активностите на капење и облекување стануваат сѐ потешки и со поголеми барања (Turnbull \& Turnbull, 1990; Crowe, 2000). Во истражувањето на VanLeit и Crowe (2002) резултатите покажале дека мајките на децата со пречки во развојот ги занемаруваат своите потреби. Во поголемиот број случаи тие не наоѓаат време за други активности, вклучувајќи ги семејните прошетки, дружење со другите членови на семејството и посветеност на домаќинството.

Bo студија спроведена на педијатриска клиника во Тајван (Chang gung Memorial hospital, Kaohsiung medical center, Chang Gung University) е утврдено дека $44 \%$ од родителите на деца со физичка попречениот имаат слабо ментално здравје, а $41,8 \%$ од мајките на деца со церебрална парализа имаат зголемен ризик од појава на психијатриски заболувања (Jen-Wen Hung, et all., 2010). И, генерално, родителите на деца со попреченост многу почесто се соочуваат со проблеми на стрес, анксиозност, депресија, соматизација, фобија и сл.

\section{1. Прв йериоя на информирање и йомош оg сииручно лице}

На многу родители им се потребни месеци, а на некои и години додека се стекнат со сила и стабилност да се помират со фактот дека имаат дете со пречки во развојот. Таа состојба и криза што настанува тешко може да се спречи, но со соодветна помош може полесно да се преброди. На нив им е потребна: емоционална йоgоршка и йолна информираности. Ова е процес што трае долго. Семејството е прво кое треба да сфати дека треба да се прифати таквото дете.

Погрешните упатства што им се дадени на родителите, непотполните факти и недоволната помош од страна на стручните лица можат да имаат сериозни последици за развојот на детето. За да се подобрат можностите и условите при информирање на родителите, а со тоа и да му се помогне на детето, потребно е да се преземат низа мерки, меѓу кои: претходно советување и едукација на родителите од страна на сите стручни лица кои во тој период од животот на детето доаѓаат во контакт со родителите (медицински сестри, лекари, социјални работници, психолози) и давање квалитетна помош на родителите во кризни ситуации кога ќе се покаже тоа како неопходно.

Многу родители кај нас и во светот зборуваат и пишуваат со горчина за тоа како кон нив се однесувал медицинскиот персонал во времето на раѓање на нивното дете (Warnock, 1978). Понекогаш на родителите не им се кажува ништо или се уверуваат дека тоа е минлива тешкотија и дека наскоро сѐ ке биде в ред.

Меѓутоа, дури и денес, постојат такви установи каде што уште при раѓањето на родителите им се кажува дека нивното дете има одреден инвалидитет и дека институционализација е единственото решение. Оваа вознемирувачка вест, секако, има огромно влијание врз понатамошните размислувања на родителите за иднината на нивното дете.

Соопштувањето за тешкотиите што ги има детето уште почесто се спроведува на груб начин, без почитување на приватноста, т.е. пред другите лица во собата во која се наоѓa мајката. Притоа, многубројните прашања кои родителите тогаш би сакале да ги 
постават едноставно нема на кого да им ги упатат. Ниту згрижувачките семејства не се подобро заштитени. Во текот на еден семинар за згрижувачи е наведен случај кога една хранителка соопштила дека воопшто не ѝ било кажано дека детето е со пречки во развојот (Mitić и сор., 2007).

Некои професионалци сѐ уште имаат погрешна перцепција за родителите и сметаат дека тие се виновни за хендикепот на детето. Turnbull и Turnbull уште во 1978 година го забележале ова кај професионалците со кои работеле. Тие никогаш не им кажале на родителите директно: „Вие го направивте ова“, но сѐ што правеле и кажувале алудирало на тоа. Раните теории во однос на етиологијата за одредени хендикепи, како што е аутизмот, ги обвинуваат родителите (најчесто мајките) за проблемите на детето. Дел од причината зошто ги обвинуваат родителите е тоа што и тие самите понекогаш чувствуваат вина за тоа што се случило. Слично на ова, професионалците, гледајќи ги децата, за родителите сметаат дека се помалку интелигентни, со намалени способности за набљудување и согледување на реалноста. Ова доага од верувањето дека „доколку детето е попречено, и со родителот сигурно нешто не е в ред“ (Wehmeyer et all., 2002). Често ниту пред отпуштање на детето од породилиште, родителите не добиваат совет што да работат понатаму и каде да бараат помош.

Розмари Шекспир ги систематизирала тешкотиите со кои се соочуваат родителите на децата со пречки во развојот. Уште во првите денови по доаѓањето на детето од породилиште е потребно семејството да донесе одлука каква медицинска интервенција треба да се преземе и кому треба да му се довери детето. Родители на дете со оштетен вид се соочуваат со еден вид тешкотии, на дете со оштетен слух со друг, а на дете со инвалидност со трет итн. Од овие причини, на барање на родителите кои имаат дете со пречки во развојот и на барање на безброј хуманитарни здруженија се изготвени безброј прирачници што треба да му помогнат на медицинскиот и на другиот персонал во вакви ситуации да реагираат на соодветен начин.

Една најчесто дадена препорака на здравствените установи е сугестијата да изготват писмен документ што ќе му биде достапен на секој родител кој има дете со развојни проблеми или постои веројатност подоцна да се здобие со нив.

\section{Сйручни лица оg UNICEF (1990) іи gале слеgниве йрейораки:}

$>$ Кога е можно, лицето кое ги информира родителите треба да биде лекар кој има искуство во работата со деца со пречки во развојот и кој е добро информиран за можностите како да им се помогне на таквите семејства и деца во непосредната средина (за расположливите институции во блиската околина во кои родителите ќе можат да се обратат), не само во раното детство, туку и за време на школувањето, па и во периодот кога тие стануваат возрасни.

$>$ Родителите мора да бидат информирани колку што е можно порано, секако, пред мајката и бебето да го напуштат породилиштето. На мајките кај кои се јавуваат бурни афективни реакции или се појавуваат силни депресивни реакции, неопходно е да им се овозможи психијатриска/психолошка помош додека не се смират. 
И таткото и мајката мора да бидат присутни кога лекарот зборува за детето. Не се препорачува информацијата за состојбата на детето лекарот да му ја даде на таткото, а потоа нему да му допушти да одбере како тоа ќе ѝ го соопшти на мајката.

$>$ Првото соопштување на родителите мора да биде приватно, без присуство на студенти или друг член од медицинскиот персонал. На наредниот состанок е корисно присуство на психолог, социјален работник, патронажна медицинска сестра или родители кои имаат слични проблеми, а кои, по оцена на организаторот на состанокот, успеале да ги надминат првобитните проблеми при приспособувањето.

Зборувајте им на родителите во присуство на бебето. Однесувајте се кон бебето на ист начин како и кон кое било новороденче, искажувајќ симпатија кон него и со зборување и со однесување.

$>$ Овозможете им на родителите повеќе пати да контактираат со стручни лица за да бидат во состојба да се соземат по шокот што го доживеале.

Ако лекарот не е во состојба веднаш да даде одговор на поставените прашања од страна на родителите, тој проблем треба да се смета за отворен и потребно е лекарот да се потруди родителите да добијат одговор од компетентни лица.

Потребно е на родителите да им се обезбедат кратки пишани упатства за проблемот на нивното дете и за можните форми на помош и поддршка.

Потребно е да се информираат родителите за постоењето хуманитарни организации и здруженија на родители и да им се овозможи контакт со нив ако родителите изразат желба за тоа.

Наведените препораки можат да бидат корисни и за згрижувачките семејства. Старателот би бил во можност да дознае со какви проблеми би можел да се соочи ако одлучи да прифати дете со пречки во развојот. Со тоа би се намалила можноста за откажување од старателство.

\section{2. Први реакции на рояийелитее кои имаай оейе со йречки во развојой}

Реакциите на родителите, во моментот на поставување на дијагнозата кај нивното дете, се исклучиво индивидуални, па нивното познавање е од големо значење за процесот на рехабилитација, бидејќи тој многу ќ зависи од ставот на родителот. Поединците во рамките на едно семејство различно го доживуваат и надминуваат истиот стрес (Van Wormer, 2007). Интензитетот и манифестацијата на реакцијата ке зависат од: личносйа на

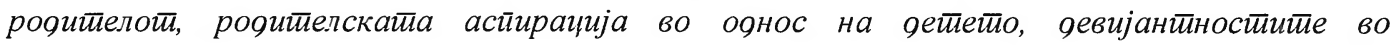
семејсиивойо, сочиоекономскиой слој на кој рояителийе му йрийаі́аай и сл. 
Најчести реакции на родителите кои имаат дете со пречки во развојот се:

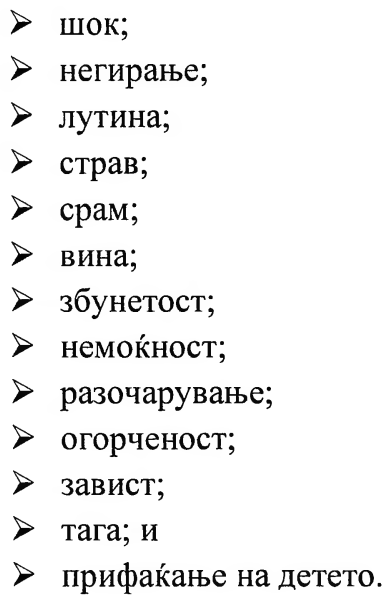

Шокот како реакција на родителите. Шокот е емоционална реакција која се манифестира кај сите родители во моментот кога дознаваат дека нивното дете е со пречки во развојот. Мал е бројот на родители кои однапред не мислат за иднината на своето сѐ уште неродено дете, за неговите способности, за неговите животни успеси. По овие очекувања не е тешко да се претпостави емоционалната состојба на родителите, кога не само што пропаѓаат нивните планови туку се поставува и прашањето за самостојната егзистенција на нивното дете.

Јачината на емоционалната реакција не ке зависи само од личноста на родителот, туку и од моментот кога е откриена попреченоста на нивното дете. Кај најтешките форми на попреченост, кај кои дијагнозата лесно се поставува веднаш по породувањето, шокот како емоционална реакција е најтежок, додека кај лесните форми на попреченост, родителите и сами со тек на времето забележуваат дека нивното дете нешто побавно се развива, па при поставувањето на дијагнозата, најчесто кога детето поаѓ на училиште, емоционалните реакции се мошне благи, што е резултат на нивното постепено привикнување.

Негирање. Претставува патолошка одбрана која е многу честа и се надоврзува на иницијалната емоционална реакција - шок.

Во психоаналитичката терминологија се употребува поимот „денегација“, а претставува општа карактеристика на луѓето да ги негираат болните сензации и факти.

Како форма на одбивање на попреченоста е и желбата на родителот да го водат детето кај разни специјалисти, а сѐ со потсвесна желба дека некој ќе ја отфрли дијагнозата или дека ќе најде некоја олеснителна причина на состојбата која може да се излекува. Често родителите не ја бараат вистината, туку професионалецот кој ќе им го каже она што тие сакаат да го чујат. Доколку нешто не им се допаѓа, тие не го почитуваат советот на професионалецот и сите негови обиди за соработка. Честопати ваквите родителите се чувствуваат загрозени кога професионалците ги советуваат и го заземаат ставот: „Никој нема да ми каже што да правам!““(Wehmeyer et all., 2002). 
Една од формите на одбивање е и водење на детето кај квазилекари (бајачки и гатачки). Оваа појава се среќава и кај интелектуалците.

Екстремната форма на одбивање се манифестира така што родителите воопшто не го прифаќаат фактот дека нивното дете е со пречки во развојот, туку сметаат дека нивното дете ќе се развива како и секое друго и дека кога ќе порасне, тоа ќе стане полноправен член на општеството.

Страв. Стравот е уште еден брз одговор, бидејќи луѓето почесто се плашат од непознато отколку од нешто што им е познато. Имањето комплетна дијагноза и некои предзнаења за идните можности на детето може да биде полесно отколку комплетната неинформираност. Во секој случај, стравот за иднината е честа емоција: „Што ќе се случи со моето дете кога ќе има 5 години, кога ќе има 12 или 21 година? Што ќе се случи со ова дете кога мене ќе ме нема?“ Потоа следуваат и други прашања: „Дали некогаш ќе учи, дали ќе оди на факултет, дали ќе има способност да сака, да живее, да се смее и да ги прави работите што ние сме ги планирале?“

И други незнаења предизвикуваат страв како што е помислата дека состојбата на детето ќе се влошува со текот на времето. Многу истражувања посочуваат дека родителите на почетокот секогаш имаат најцрни мисли, го очекуваат најлошото, присетувајќ се на лица со инвалидност кои ги познавале.

Збунетост. Збунетоста, исто така, го одбележува овој трауматски период. Како резултат на непотполно разбирање на тоа што се случува и што ќе се случи, збунетоста сама по себе предизвикува несоница, неспособност за донесување одлуки и ментално преоптоварување. При ваква траума информациите изгледаат испревртени и лажни, родителите слушаат зборови кои никогаш претходно не ги слушнале и термини кои опишуваат нешта што тие не можат да ги разберат. Сакаат да дознаат за што станува збор, но сѐ уште сите информации што ги добиваат им изгледаат бесмислени. Често пати родителите не се на иста бранова должина со лицето кое се обидува да комуницира со нив за попреченоста на нивното дете.

Вина и срам. Според многу автори, овие две емоционални реакции се мошне чести. Многу родители ги доживуваат своите деца како дел од самите себе, како свое продолжение, па бидејќи тоа е хендикепирано, се чувствуваат виновни и сметаат дека тие самите придонеле за појавата на ваквата состојба. Изложувањето на детето на осудувачките погледи на другите може да претставува големо понижување за родителите. Врз основа на ваквото мислење, многу родители го преиспитуваат своето минато, сметајќи дека хендикепираното дете дошло како резултат на казна за нивно претходно однесување.

Кај родителите честопати се појавува амбивалентно чувство кон детето, т.е. истовремено се појавува и позитивно и негативно чувство. Конфликтот помеѓ овие две спротивни чувства создава нова реакција - вина во однос на детето. Вината останува несвесна и се манифестира како реакција на отфрлање, претерана заштита и сл.

Чувството на вина е далеку поизразено кај родители кои се религиозни, понатаму во ситуации кога детето е непосакувано или во семејства каде што постои мислење дека детето со хендикеп ќе доведе до дегенерација на семејството. 
Од некои причини, луѓето ги прифаќаат физичките пречки како дел од животот и не ги обвинуваат родителите што донеле на свет дете со физички инвалидитет. Меѓутоа, други (вклучувајќи и некои стручњаци од областа на менталното здравје) како да покажуваат со прст на родителите чии деца страдаат од емоционални и ментални нарушувања. Родителите можат да чувствуваат срам кога по откривањето на пречки во развојот кај нивното дете, треба да посетат детски психолог или семеен психотерапевт. Може да се јави чувство на стигматизирање и покрај фактот што тоа искуство би можело да биде едно од најпозитивните настани во животот на родителите (Ретклиф, 2008).

Огорченост (лутина, агресија) Се јавува кај оние родители кои во своето хендикепирано дете гледаат препрека за нивно лично напредување во социјалната средина и релацијата со околината. Кога средината не го прифаќа нивното дете, тогаш тие искажуваат огорченост како кон детето, така и кон средината.

Реакцијата може да се манифестира на разни начини. Еден од начините е родителите да ги обвинуваат докторите и наставниците за неуспесите на своето дете, а ова во психоаналитичката литература е познато под името проекција.

Првите агресивни реакции родителите често ги упатуваат кон докторите, акушерите, медицинските сестри и останатиот медицински персонал кој учествувал во текот на породувањето или кон лицата кои учествувале во утврдувањето на дијагнозата (дефектолози, психолози, социјални работници).

Постои и т.н. автоагресија кога лицето се свртува кон сопствената личност со силно чувство на вина (наследност или казна за грев).

Во истражувањето на Павковиќ (2000), родителите во $35 \%$ од случаите ги обвинувале докторите, во $13,5 \%$ се обвинувале себеси, додека во 7,8\% обвинувале некој друг за состојбата на нивното дете. Интересен е податокот што многу ретко (само 0,7\%) го обвинувале својот брачен другар.

Завист. Претставува реакција на родителите со деца со пречки во развојот кон туѓите деца. Оваа реакција е посебно нагласена кога на родителите детето со хендикеп им е единствено, додека во семејствата со повеќе деца ова чувство на завист го компензираат здравите и успешни деца.

Отфрлање. Претставува најтешка реакција која произлегува првенствено од личноста на родителот. Овие родители во основа се перфекционисти. Тие имаат одредени цели за своите деца, тежнеат нивните деца да бидат најдобри и пред нив поставуваат големи барања кои тие не можат да ги исполнат. Поради тоа, родителите се незадоволни, а детето го доживува тоа како скратување на љубов, се чувствува отфрлено и почнува несоодветно да се однесува. Родителите не можат да го сфатат ова однесување и така се создава затворен круг (circulus vitiosus).

Отфрлањето се јавува кога детето не може да покаже одредени квалитети и може да се манифестира на различни начини. Се сретнуваат йоййолно и йарцијално отфрлање. Пример на потполно отфрлање е оставање на детето на улица или сместување во институција, а парцијално отфрлање е кога на детето не му се даваат оброци навреме, кога го оставаат само дома, кога му даваат разни забрани за играње, гледање телевизија или детето го облекуваат со стара и износена облека. 
Постојат и маскирани манифестации на одбивање, како што е критикување на детето, исмевање, давање разни погрдни имиња и сл.

Тага. Тагата е општа реакција и се јавува кај сите родители што имаат дете со пречки во развојот. Olshansky (1962) нагласува дека сите родители патат од хронична тага, но нејзината големина зависи од примарниот карактер на родителот. Овој автор смета дека оваа тага не претставува патолошка реакција, туку природен и нормален одговор.

Павковиќ (2000), на примерок од 150 родители, ги испитувал првите реакции на родителите на сознанието дека нивното дете има оштетен слух и дошол до следниве резултати:

најдоминантна реакција била тагата (84\%), потоа вознемиреноста (30\%), додека со шок реагирале $18,5 \%$ од родителите;

пронајдени се значителни разлики во реакциите помеѓу мајките, кои претежно тагувале, и татковците, кои изјавиле дека нивната реакција била нормална.

Прифаќање на детето. Најважно е родителите да сфатат дека е потребно да му се покаже љубов на детето и да се прифати такво какво што е со сите негови доблести и мани (Šprajc-Bilen, 2009).

Според Robert Ingalls, процесот на прифаќање на детето со пречки во развојот ги вклучува следниве карактеристики:

$>$ родителите кои го прифаќаат своето дете се способни да ги видат неговите способности и потенцијали, но и неговите недостатоци и слабости;

$>$ овие родители го набљудуваат детето на реален начин, согледувајќ ги одредените тешкотии што му ги нанесува ова дете на семејството, но не се оптоварени со самообвинување, со претерана тага или вина, т.е. не е загрозено функционирањето на семејството;

овие родители се способни слободно да дискутираат за своите деца, како во кругот на своето семејство така и со другите луѓе, без чувство на срам;

$>$ родителите се обидуваат да го лекуваат и да го едуцираат детето на најдобар начин, но без барање чудотворец;

$>$ овие родители му даваат љубов на ова дете како и на своите здрави деца, не го отфрлаат, но, исто така, не му даваат ни претерана заштита;

родителот кој го прифаќа своето дете не го посветува целото свое време и енергија само на детето со пречки, што би било на штета на другите деца во семејството.

\section{Заклучок}

Клучна функција на семејството е да му овозможи на детето безбедно и соодветно опкружување кое му дава поддршка, му овозможува да развива знаења, вештини, ставови и однесувања неопходни да израсне во возрасна личност која ќе даде продуктивен придонес за себе, семејството, заедницата и за општеството. Родителите треба да го оформат поголемиот дел од искуствата на детето со своите верувања и со однесувањето што го покажуваат кон него. Верувањата на родителите вклучуваат ставови и знаења што се разликуваат од култура до култура. 
Квалитетот на односите помеѓу родителите и децата зависи од особините на родителите, но и на самото дете, кое веќе од раѓање има активна улога во тој однос. 


\section{Литерапура}

Ali, L. (2008). [Online] Having Kiks Makes You Happy. Available from: http://www. newsweek.com/id/143792 [Accessed $10^{\text {th }}$ March 2013].

Boyce, P., Hunter, C., \& Howlett, O. (2003). The benefits of daylight through windows. Troy, NY: Rensselaer.

Crowe, T. K. (1993). Time use of mothers with young children: The impact of a childs disability. Developmental Medicine and Child Neurology. 88, 125-138.

Jen-Wen Hung, Yee-Hwa Wu, Yi-Chien Chiang RN, Wen-Chi Wu, Chao-Hsing Yeh 2, R. N. (2010). Mental Health of Parents Having Children with Physical Disabilities. Chang Gung medical journal. 33(1):82-91.

Kara Ayers. (2010). [Online] Self-care: Why Parents of Children with Disabilities Must Nurture Themselves. Available from: URL: http:/www.disaboom,com/children-withdisabilities/self-care-why-parents-of-children-with-disabilities-must-nurture-themselves [Accessed $2013 \mathrm{Jan}$ ].

Mitić, M. i sar. (2007). Hraniteljstvo kao izazov. Beograd: Familia.

Olshansky, S. (1962). Chronic sorrow: A response to having a mentally defective child. Social Casework. 43(4)21-23.

Pavković I. (2000). Evaluacija porodice deteta oštećenog sluha. Magistarski rad. Beograd: Defektološki fakultet.

Pavković I. (2003). Porodica i dete oštećenog sluha. Beograd: Zadužbina Andrejević.

Rot, N. (2006) Psihologija grupa. Beograd: Zavod za udžbenike.

Seibt, T. H. (1996). Nontraditional Families. In: Treating the Changing Family, Harvey M., editors. USA: John Wiley \& Sons.

Seligman, M., Darling, R. B. (2007). Ordinary families, special children-A systems Approach to Childhood Disability. New York: The Guilford Press.

Snowdon, A. W, Cameron, S., Dunham, K. (1994). Relationships between stress, coping resources, and satisfaction with family functioning in families of children with disabilities. Canadian Journal of Nursing Research. 26(3)63-76.

Stamenkova-Trajkova, V., Trajkov, I. (1997). Family and early treatment of children with psychical difficulties in their development. Journal of Special Education and Rehabilitation. 1(2)59-66.

Turnbull, A. \& Turnbull H. (1990). Families, professionals, and exceptionality: A special partnership. 2 nd ed. New York: Merill.

UNICEF. (1990). Svetska deklaracija o opstanku, zaštiti i razvoju dece. Pariz.

Utley, C. A., Hoehn, T. P., Soraci, S. A. \& Baumester A. A. (1993). Motivational orientation and span of apprehension in children with mental retardation. The Journal of genetic psychology. 154, 289-295.

VanLeit, B., \& Crowe, T. K. (2002). Outcomes of an occupational therapy program for mothers of children with disabilities: Impact on satisfaction with time use and occupational performance. American Journal of Occupational Therapy. 56, 402-410. 
Van Wormer, K., Besthorn, H. F. (2007). Human Behavior and the Social Environment, Macro Level: Groups, Communities, and Organizations. Oxford University Press.

Warnock, H. M. (1978). Special Education Needs. London: Her Majesty's Stationery Office.

Wehmeyer, L. M., et all. (2002). Teaching Students with Mental Retardation: Providing access to the general curriculum. Paul H. Brookes Publishing Co.

Widerstrom, A. H, \& Goodwin, L. D. (1987). Effects of an infant stimulation program on the child and the family. Journal of the Division for Early Childhood. 11(2)143-153.

Čudina-Obradović, M., Obradović, J. (2006). Psihologija braka i obitelji. Zagreb: Golden marketing- Tehnička knjiga.

Šprajc-Bilen, M. (2009). Pružanje pomoći obiteljima s djecom u kriznim situacijama. Zagreb: Medicinska naklada.

Редклиф, Ч. С. (2008). Восйийувајйе іи своийе gеиа без йомиіање на іласой. Скопје: Клуб матица.

Чичевска-Јованова Н., Димитрова-Радојичиќ Д. (2013). Родители на деца со пречки во

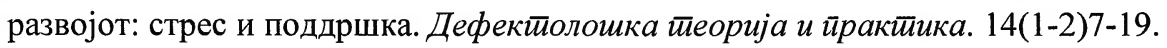


Natasa CICEVSKA-JOVANOVA

Olivera RASIKJ-CANEVSKA

\section{FIRST REACTIONS OF THE PARENTS OF CHILDREN WITH DEVELOPMENTAL DISORDERS}

"All happy families resemble one another, but every unhappy family is unhappy on its own way" Lav Tolstoj (in Anna Karenina)

\section{Summary}

When the parents for the first time find out that their child has some developmental disabilities, their lives change instantly and they have to face many challenges. Above all, they have to change their expectations about the child, which they have set before, have to cope with the additional financial costs (payment of drugs, additional treatments, private lessons, transport), as well as numerous absences from the work or to quit the job, because someone has to take care of the child with developmental disabilities. Some of them may experience a social isolation by the family, neighbors and friends.

The reactions of the parents during the diagnosis of their child are exclusively individual, so their knowledge is crucial for the process of the rehabilitation, because it will depend a lot from the parents' attitude. The intensity and the manifestation of the reaction depend of the: personality of the parent, parent's aspiration about the child, deviations in the family, socio-economic status of the parents and etc.

The most common reactions of the parents, when they first time confronted with the fact that they have a child with developmental disabilities are: shock, denial, anger, fear, shame, guilt, confusion, powerless, disappointment, indignation, jealousy and sorrow.

Keywords: FAMILIES, PARENTS, CHILDREN WITH DEVELOPMENTAL DISABILITIES, REACTIONS 